\title{
The potential of Mesangat Lake, East Kutai, Indonesia as an essential ecological area for habitat conservation of critically endangered Crocodylus siamensis
}

\author{
SUDRAJAT ${ }^{1, \bullet}$, HIKMA AMALIA SALEH ${ }^{2,3}$ \\ ${ }^{1}$ Laboratory of Ecology and Biodiversity, Faculty of Mathematics and Natural Sciences, Universitas Mulawarman. Jl. Barong Tongkok, Gunung Kelua, \\ Samarinda 75242, East Kalimantan, Indonesia. Tel.: +62-541-749140, "email: sudrajat.fmipa@ gmail.com \\ ${ }^{2}$ Department of Environmental Science, School of Graduates, Universitas Mulawarman. Gunung Kelua, Samarinda 75242, East Kalimantan, Indonesia \\ ${ }^{3}$ The Office of Environmental Service, East Kutai District Government in Sangatta. J1. Pertanian, Teluk Lingga, Sangatta Utara, East Kutai 75683, \\ East Kalimantan, Indonesia
}

Manuscript received: 20 September 2019. Revision accepted: 7 October 2019.

\begin{abstract}
Sudrajat, Saleh HA. 2019. The potential of Mesangat Lake, East Kutai, Indonesia as an essential ecological area for habitat conservation of critically endangered Crocodylus siamensis. Biodiversitas 20: 3126-3133. The Siamese crocodile, Crocodylus siamensis, is one of the most threatened reptile species in the world with IUCN Red List status of Critically Endangered. This study aims to investigate and assess the biogeophysical conditions of Mesangat Lake area, East Kutai District, East Kalimantan Province, Indonesia as an essential ecological area for $C$. siamensis conservation outside biodiversity conservation areas. Data was collected through direct survey using spotlight technique at night, tracking, observation and interviews with local fishermen. The results showed that the biogeophysical conditions of Mesangat Lake habitat in Long Balau, Loah Toh and Abang areas still support C. siamensis population which was marked by the presence of its nests and the occurrence of 17 individuals with sizes between 30 and $50 \mathrm{~cm}$ in length. Habitat conditions in the form of lake waters had depths between $30-110 \mathrm{~cm}$, low currents, and covered with aquatic plant species for resting, nesting and basking, as well as contained sufficient diversity of fish and other prey. A nest was also found in the form of mound of plants measuring $\pm 45 \mathrm{~cm}$ high and $\pm 75 \mathrm{~cm}$ wide which contained 20 eggs with an average length of $\pm 8.45 \mathrm{~cm}$, an average width of \pm $4.9 \mathrm{~cm}$. Potential factors that threaten $C$. siamensis habitat included siltation of water bodies caused by invasive weeds, over-exploitation of fishes and conversion of lake land into plantations and/or agriculture lands. Based on the results of this study, it can be stated that Mesangat Lake has the potential to be designated as an essential ecological area of $C$. siamensis habitat. Through this strategy, it is hoped that there will be good collaboration between local government and concession rights holders, NGOs and local communities to participate in the conservation of $C$. siamensis. In the area of the lake, zoning can be classified into areas of nesting, closed areas, playing and sunbathing, limited fishing, recreation.
\end{abstract}

Keywords: Essential ecological areas, Crocodylus siamensis, East Kalimantan, habitat, Mesangat Lake, utilization zones

\section{INTRODUCTION}

Siamese crocodile, Crocodylus siamensis, is a mediumsized freshwater crocodile with the males usually measuring of $3.5 \mathrm{~m}$ long and females of $2.5 \mathrm{~m}$ (Crocodile Specialist Group 2013). C. siamensis is one of the most threatened crocodile species in the world. In 1992, Thorbjarnarson reported that this animal was declared as endangered in the wild and since 1996 it was listed under the International Union for Conservation of Nature and Natural Resources (IUCN) Red List Status as 'Critically Endangered' (Simpson and Bezuijen 2010). At present, significant wild populations are known to exist in Cambodia and Kalimantan. In small number, there are scattered remnant populations found in several parts of Laos. In Vietnam and Thailand, C. siamensis is considered extinct in the wild. In Cambodia, Platt et al (2006) reported that $C$. siamensis still exists and remains in fragmented locations. Siamese crocodiles are found in a variety of freshwater habitats, including rivers, lakes, swamps. In Indonesia, the conjoined species of $C$. siamensis spread at first in the islands of Java and Kalimantan. According to
Thorbjarnarson (1992), its existence in Indonesia is stated as being almost extinct. Cox et al.(1993), conducted a study and found that $C$. siamensis still exists in Mesangat Lake, Muara Ancalong Sub-district, East Kutai District, East Kalimantan Province, Indonesia. Since Cox's discovery, Mesangat Lake was later included in the IUCN map as a habitat for Siamese crocodiles. In 1996, the Siamese crocodile species (C. siamensis) was declared as Critically Endangered category by IUCN.

During the last decade, the results of studies on the ecology of $C$. siamensis have begun to be widely publicized although this crocodile is less widely known. Ihlow et al. (2014) reported that the number of $C$. siamensis was estimated to the global population be less than 1,000 adult individuals in the wild. Crocodile skin trading activities and the search for crocodile tillers to be farmed in the mid and the late 20th century were considered as the main cause of its population decline. At present the threats still exist, including illegal egg collection, land conversion so that the habitat is lost or narrowed, incidental capture by the community and the vulnerability of the remaining population due to the small numbers, indicating that 
without intervention in conservation efforts, the crocodile population conjoined will continue to decline.

Staniewicz et al. (2018) reported that in Mesangat Lake region, there are two types of crocodiles protected and their life is sympatric, namely $C$. siamensis and $C$. tomistoma in their juvenile stage. This sympatric nature is characterized by different ecological niches to minimize competition between species. Based on the comparison of habitats and the analysis of the contents of stomach, it suggested that $C$. tomistoma Schlegelii was found mostly in flooded forest areas, while $C$. siamensis mainly lived in open areas.

All the remaining small and fragmented subpopulations are threatened by illegal collection, conversion of lakes into plantations, mining and other activities, and overfishing by local communities. Without conservation intervention, the remaining population will continue to decline. Lack of information regarding this species has an impact on determining the right conservation strategy. On the other hand, the rapid expansion of plantations, settlements, mining, and other activities and the ignorance of conservation principles increasingly threatens the preservation of the habitats of Siamese crocodiles. Therefore, there is a need for study on conservation areas outside the nature protection areas determined by the government. Until now, information regarding the habitat of $C$. siamensis is still not widely known.

The purpose of this study is to investigate the biogeophysical conditions of Mesangat Lake as a habitat for in situ conservation of $C$. siamensis, population distribution, supporting factors and activities that can threaten its survival. The results are expected as a reference and consideration for management actions of Mesangat Lake as an ecological essential area that can support the sustainability of the $C$. siamensis in their habitat in collaboration with the society.

\section{MATERIALS AND METHODS}

\section{Study location}

Mesangat Lake is located in Long Mesangat Subdistrict, East Kutai District, East Kalimantan Province located between $00^{\circ} 30^{\prime} 07^{\prime \prime}$ North and 116 $41^{\prime} 54^{\prime \prime}$ East (Figure 1). The lake covers an area of 18,500 hectares, located between the Kelinjau River and Telen River.

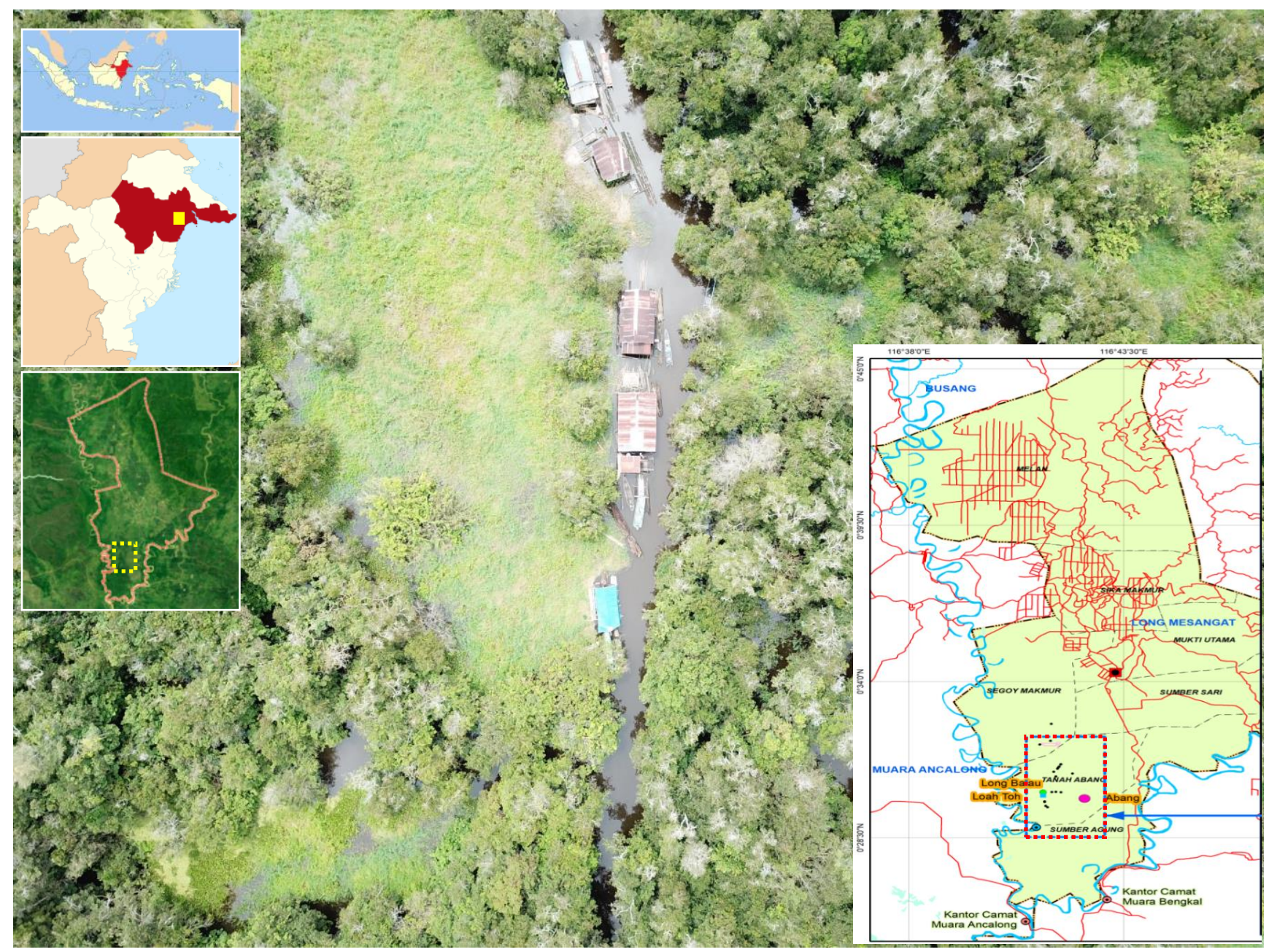

Figure 1. Location of study sites in the Mesangat Lake, Subdistrict of Long Mesangat, East Kutai District, East Kalimantan Province, Indonesia. Aerial photograph of Mesangat Wetland Area taken from Ulin Foundation, Samarinda, Indonesia 


\section{Field survey}

The survey to investigate crocodile habitats was conducted between October and December 2018 during the day by walking and on boats. The survey to seek the presence of crocodiles was carried out using night spotlight technique on wooden boat equipped with a diesel outboard motor. Following the method carried out by Savini et al. (2012), the crocodiles that were caught were measured and released again. Data on the existence of crocodiles, plant species and geographical coordinate locations were recorded to create distribution maps. Environmental data of the habitat were collected from related institutions, including geological, climate, land cover, hydrological and land use data.

\section{RESULTS AND DISCUSSION}

Biogeophysical characteristics of Crocodylus siamensis habitat

Mesangat Lake is a lake or basin of swamp waters, in local languages, it is called Kenohan or Long. The lake is connected by small rivers to the main river, the Kelinjau River and the Kedang Kepala River. This lake is made up of riparian, lowland forests, swamps, swamps and lakes that form one unit. There are 3 (three) rivers namely the Mesangat, Senyun, and Sekgoy Rivers. The river on the left is the Sekgoy River, in the middle is the Mesangat River and on the right the Senyun River. To the left and right upstream of the Mesangat River are lowland forests dominated by Rattan and other shrubs and there are streams such as Long Putu, Long Saka.

The topography of the lake is flat with an altitude of 0 $20 \mathrm{~m}$ above sea level ( $\mathrm{m}$ asl.). The dry season lasts from June to October and the rainy season occurs from November to May. The average daily temperature is $26.3^{\circ} \mathrm{C}$, with the highest average temperature of $32.5^{\circ} \mathrm{C}$ and the lowest average temperature of $23.0^{\circ} \mathrm{C}$ (Table 1). The water level varies throughout the year, ranging from 31 to $381 \mathrm{~cm}$ depending on the season. The lake's geological formation consists of quarterly alluvium deposits on the edge of the lake and the surrounding large river. The rock structure is composed of clay, silt, sand, and gravel, which are not yet integrated.
The pattern of river flow is dendritic and water flows at a slow speed because the river's body is meandering, causing inundation to occur in low areas. Lake water level is influenced by river inlet water discharge and direct rainfall to the surface of the lake does not result in rising water levels. This area has the highest tide and tide area of almost 4 meters and is highly dependent on the waters upstream of the lake (i.e. Sekgoy, Mesangat, and Senyun Rivers).

The land cover in Mesangat Lake consists of swamp forests, swamp shrubs, oil palm plantations and aquatic floating vegetation (Figure 2). Based on land use, the entire Mesangat Lake area is in the status of other use areas (area penggunaan lain) and most of them are within the concession of PT. Cipta Davia Mandiri (CDM), a subsidiary of PT. REA Kaltim Oil Palm Plantations Group.

\section{Assessment of the existence of Crocodylus siamensis and its habitat preferences}

From all observations of crocodiles in Mesangat Lake, 19 objects were found, consisting of $31 \%$ identified as $C$. siamensis measuring between 30 to $50 \mathrm{~cm}$ in length, $15 \%$ as Tomistoma schlegelii and the rest could not be identified or only the eyes, "Eyes Only" (EO). Siamese crocodiles like a lot of bright areas, on the edge of a stretch of water hyacinth, Eichhornia crassipes (eceng gondok). The results of the study are presented in Table 2 and Figure 3.

Based on the data in Table 2, it can be seen that $C$. siamensis found were in the level of hatchlings (adolescents) with size of $30-60 \mathrm{~cm}$ in length. Adult crocodiles were not found which is likely caused by a narrow and shallow range of movement in the lake. $C$. siamensis hatchlings preferred to hide under aquatic plants such as E. crassipes, Salvinia molesta (kiyambang, water spikes) and Ipomoea sp. (kangkung). In terrestrial vegetation environment, hatchlings were found predominantly among Hanguana malayana (bakung), sometimes were also found between Hypolytrum nemorum (selingsing) and Scleria sumatrensis (predang, Sumatran scleria). The location of habitat with the presence of $C$. siamensis was in Long Balau, Loah Toh and Abang. C. siamensis likes open areas full of direct sunlight, with dense floating plant communities.

Table 1. Climatic conditions in the area around Mesangat Lake, East Kalimantan, Indonesia in the period of 2008-2018

\begin{tabular}{|c|c|c|c|c|c|c|c|c|}
\hline \multirow{2}{*}{ Month } & \multirow{2}{*}{$\begin{array}{c}\text { Intensity rainy } \\
(\mathrm{mm})\end{array}$} & \multirow{2}{*}{$\begin{array}{c}\text { Day rainy } \\
\text { (day) }\end{array}$} & \multicolumn{3}{|c|}{ Temperature $\left({ }^{\circ} \mathrm{C}\right)$} & \multirow{2}{*}{$\begin{array}{c}\text { Humidity } \\
(\%)\end{array}$} & \multirow{2}{*}{$\begin{array}{l}\text { Wind speed } \\
\text { (Knot) }\end{array}$} & \multirow{2}{*}{$\begin{array}{c}\text { Wind } \\
\text { rose }\end{array}$} \\
\hline & & & Max & Min & Mean & & & \\
\hline January & 220 & 13 & 34.5 & 21.5 & 26.6 & 86.0 & 4.0 & NW \\
\hline February & 263 & 11 & 33.3 & 22.5 & 24.4 & 94.0 & 4.0 & $\mathrm{NE}$ \\
\hline March & 272 & 12 & 33.9 & 20.9 & 26.0 & 89.0 & 3.0 & SW \\
\hline April & 312 & 14 & 32.8 & 23.2 & 25.8 & 85.0 & 4.0 & $\mathrm{E}$ \\
\hline May & 275 & 15 & 33.0 & 23.3 & 27.0 & 87.0 & 3.0 & SW \\
\hline June & 275 & 11 & 32.1 & 23.4 & 26.9 & 83.0 & 3.0 & SW \\
\hline July & 106 & 10 & 32.8 & 23.3 & 26.5 & 84.0 & 3.0 & SW \\
\hline August & 105 & 10 & 31.5 & 23.4 & 26.2 & 86.0 & 3.0 & SW \\
\hline September & 137 & 11 & 31.9 & 23.8 & 26.9 & 83.0 & 3.0 & $\mathrm{~S}$ \\
\hline October & 156 & 10 & 31.5 & 23.4 & 26.2 & 86.0 & 3.0 & SW \\
\hline November & 283 & 12 & 32.2 & 23.6 & 26.8 & 85.0 & 3.0 & W \\
\hline December & 274 & 11 & 30.0 & 23.6 & $26 / 0$ & 85.0 & 5.0 & W \\
\hline Total & 2678 & 140 & - & - & - & - & - & - \\
\hline Mean & 223 & 12 & 32.5 & 23 & 26,3 & 85.8 & 3.4 & - \\
\hline
\end{tabular}

Note: The Office of Agriculture Service, East Kutai District Government in Sangatta 2018 

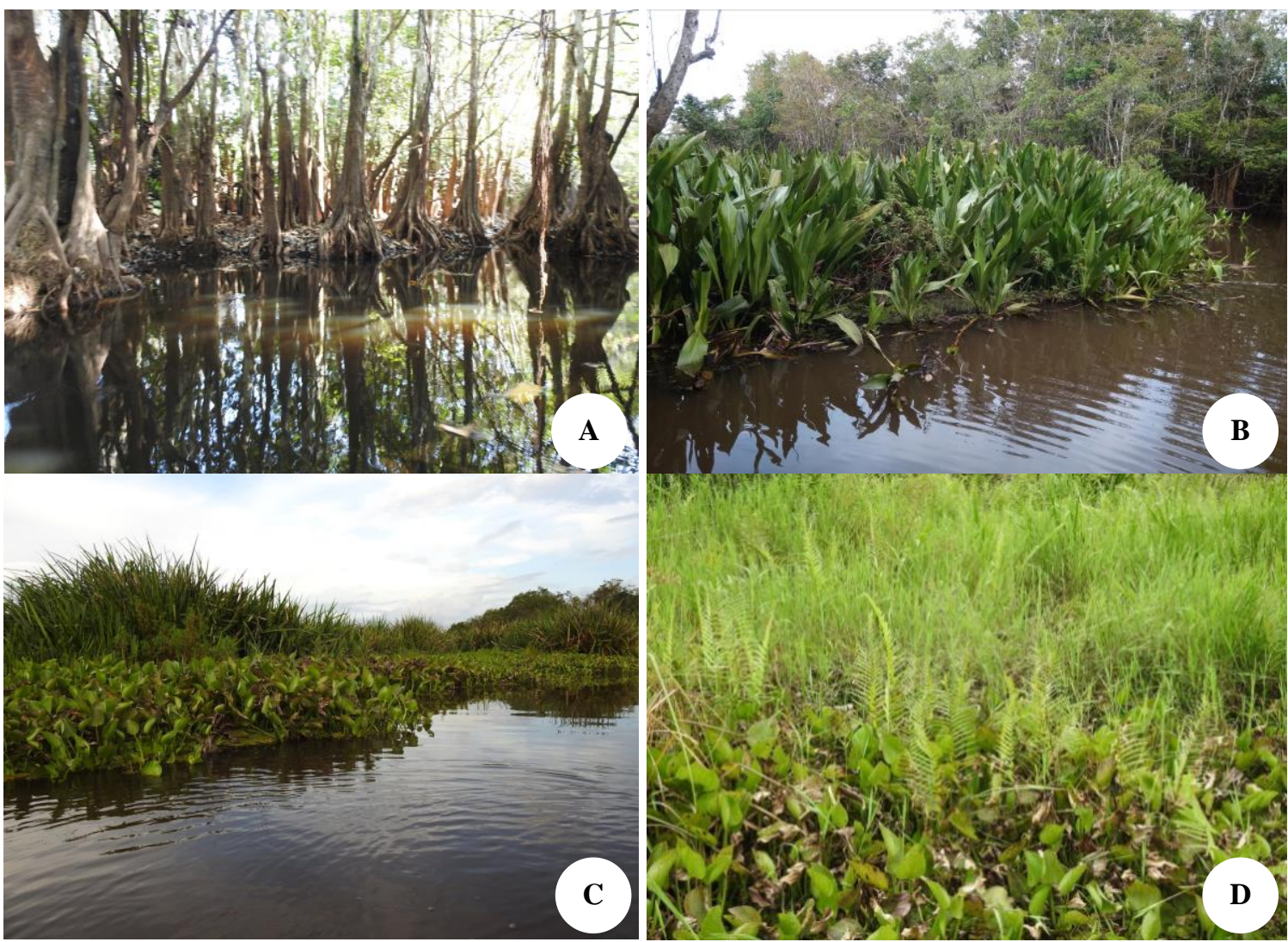

Figure 2. Vegetation types in Mesangat Lake, East Kalimantan, Indonesia. A. Lophopetalum javanicum (perupuk), B. Hanguana malayana (bakung), C. Eichhornia crassipes (eceng gondok), D. Leersia hexandra grass

Tabel 2. The distribution of Crocodylus siamensis in Mesangat Lake, East Kalimantan, Indonesia in 2018

\begin{tabular}{|c|c|c|c|c|c|c|c|}
\hline \multirow[b]{2}{*}{ Code } & \multirow[b]{2}{*}{ Time } & \multirow{2}{*}{$\begin{array}{l}\text { Body } \\
\text { length } \\
(\mathrm{cm})\end{array}$} & \multicolumn{2}{|c|}{ Coordinate } & \multirow[b]{2}{*}{ Location } & \multirow{2}{*}{$\begin{array}{l}\text { Water } \\
\text { depth } \\
\text { (cm) }\end{array}$} & \multirow{2}{*}{ Aquatic plants that dominate } \\
\hline & & & East & North & & & \\
\hline TS001 & 19.50 & 30 & $116^{\circ} 41^{\prime} 45.77^{\prime}$ & $0^{\circ} 30^{\prime} 05.55^{\prime \prime}$ & Border to Abang & 30 & $\begin{array}{l}\text { Hanguana malayana, Ipomoea sp., Salvinia } \\
\text { molesta, Scleria sumatrensis }\end{array}$ \\
\hline TS 002 & 20.05 & 30 & $116^{\circ} 41^{\prime} 42.57^{\prime}$, & $0^{\circ} 30^{\prime} 49.05^{\prime \prime}$ & Long Balau (Folden) & 100 & Gluta renghas, Lophopetalum javanicum \\
\hline CRO001 & 21.12 & 36 & $116^{\circ} 41^{\prime} 42.28^{\prime \prime}$ & $0^{\circ} 30^{\prime} 45.37^{\prime \prime}$ & Long Balau (Bakungan) & 100 & L. javanicum, H. malayana, S. molesta \\
\hline ES 001 & 19.35 & 36 & $116^{\circ} 41^{\prime} 49.62^{\prime}$, & $0^{\circ} 30^{\prime} 58.07 ”$ & Long Balau (Kepala Segoi) & 85 & L. javanicum, S. sumatrensis \\
\hline CRO002 & 21.00 & 36 & $116^{\circ} 41^{\prime} 51.44^{\prime \prime}$ & $0^{\circ} 31^{\prime} 00.03 ”$ & Long Balau (Kepala Segoi) & 75 & L. javanicum, Gluta renghas, S. sumatrensis \\
\hline CS 001 & 22.15 & 40 & $116^{\circ} 41^{\prime} 53.47^{\prime}$, & $0^{\circ} 31^{\prime} 04.95 \prime$ & Long Balau & 75 & H. malayana, Eichhornia crassipes, S. molesta \\
\hline ES 002 & 20.00 & 40 & $116^{\circ} 41^{\prime} 53.21^{\prime \prime}$ & $0^{\circ} 31 ’ 04.52 ”$ & Long Balau & 90 & $\begin{array}{l}\text { H. malayana, S. molesta, E. crassipes, } \\
\text { Cyclosorus interruptus }\end{array}$ \\
\hline CS 002 & 22.05 & 40 & $116^{\circ} 41^{\prime} 28.72^{\prime}$, & $0^{\circ} 29^{\prime} 46.39 \prime$ & Loah Toh & 75 & C. interruptus, S. sumatrensis, E. crassipes \\
\hline CS 003 & 24.30 & 45 & $116^{\circ} 41^{\prime} 39.59^{\prime \prime}$ & $0^{\circ} 31 ' 43.96 ”$ & Loah Toh & 90 & E. crassipes, $C$. interruptus, Ipomoea sp. \\
\hline TS 003 & 00.55 & 40 & $116^{\circ} 41^{\prime} 45.77^{\prime \prime}$ & 0'30’39.12” & Long Balau (Batangan) & 90 & L. javanicum, G. renghas \\
\hline CS 004 & 01.15 & 40 & $116^{\circ} 41^{\prime} 32.87^{\prime \prime}$ & $0^{\circ} 29^{\prime} 34.24 \prime$ & Loah Toh & 120 & H. malayana, S. sumatrensis, E. crassipes \\
\hline Es 003 & 19.55 & 36 & $116^{\circ} 41^{\prime} 30.27^{\prime \prime}$ & $0^{\circ} 30^{\prime} 06.15^{\prime \prime}$ & Loah Toh & 120 & H. malayana, E. crassipes, $S$. sumatrensis \\
\hline Es 004 & 22.00 & 50 & $116^{\circ} 41^{\prime} 53.57^{\prime}$, & $0^{\circ} 30^{\prime} 05.96 ”$ & Long Balau (bakung) & 105 & S. sumatrensis, E. crassipes \\
\hline Es 005 & 23.05 & 36 & $116^{\circ} 41^{\prime} 38.82^{\prime}$, & $0^{\circ} 30^{\prime} 05.96^{\prime \prime}$ & Long Balau & 100 & S. sumatrensis, E. crassipes \\
\hline Nest & 17.00 & & $116^{\circ} 41^{\prime} 48.13^{\prime \prime}$ & $0^{\circ} 30^{\prime} 55.76^{\prime \prime}$ & Long Balau & 140 & $\begin{array}{l}\text { S. sumatrensis, } C \text {. interuptus, Lersis } \\
\text { hexandra (kelementa), E. crassipes }\end{array}$ \\
\hline CS005 & 21.05 & 40 & $116^{\circ} 41^{\prime} 28.56^{\prime \prime}$ & $0^{\circ} 29^{\prime} 46.48^{\prime \prime}$ & Loah Toh & 140 & $\begin{array}{l}\text { S. sumatrensis, C. interuptus, S. molesta, E. } \\
\text { crassipes }\end{array}$ \\
\hline Nest & 17.05 & & $116^{\circ} 41^{\prime} 21.05^{\prime}$, & $0^{\circ} 31^{\prime} 46.76 ”$ & $\begin{array}{l}\text { Long Balau (Border to } \\
\text { Kelindimut) }\end{array}$ & 150 & $\begin{array}{l}\text { Predang } S . \text { sumatrensis, } C \text {. interuptus, } L . \\
\text { hexandra, E. crassipes }\end{array}$ \\
\hline CS006 & 22.05 & 50 & $116^{\circ} 41^{\prime} 37.61^{\prime \prime}$ & $0^{\circ} 31^{\prime} 54.26^{\prime \prime}$ & $\begin{array}{l}\text { Long Balau (Border to } \\
\text { Kelandimut) }\end{array}$ & 110 & Hypolytrum nemorum, S. molesta \\
\hline
\end{tabular}

Note: TS: Tomistoma schlegelii; Cs: Crocodylus siamensis; CRO: Object Cannot be captured, but according to fishermen information is Crocodile, it can be TS or Cs based on shape, skin color, and movement. ES: Eye Shine, object cannot be captured but can be identified as a crocodile based on the look in its eyes 


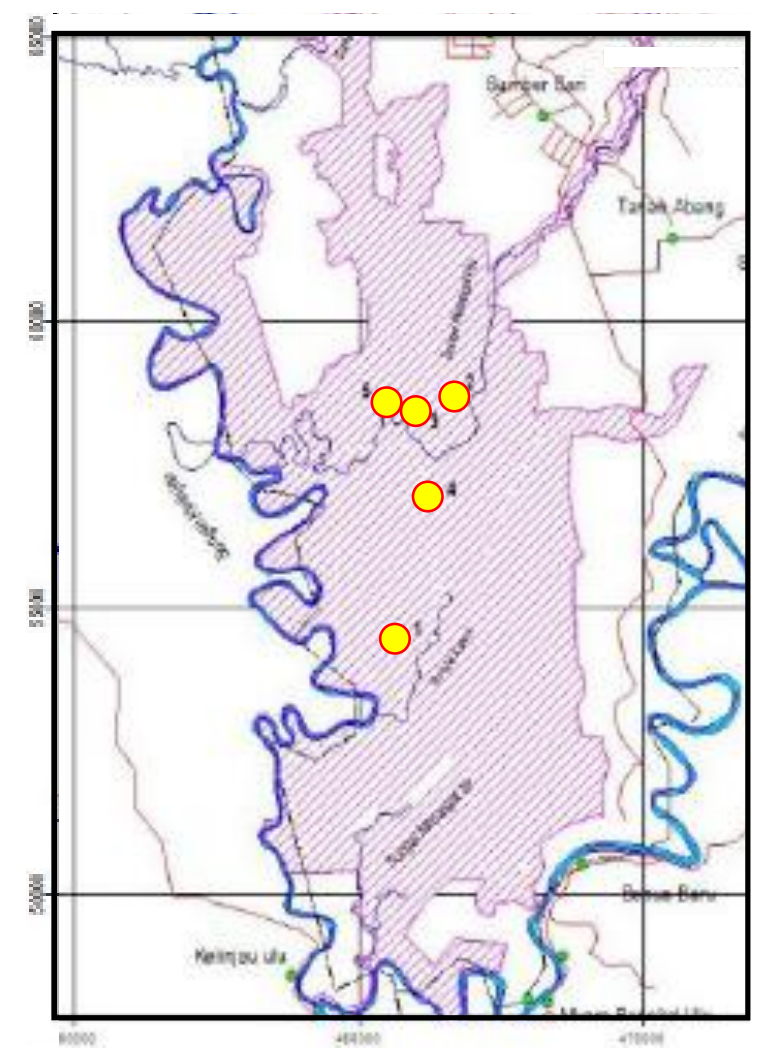

Figure 3. Map of Crocodylus siamensis distribution in Mesangat Lake, Long Mesangat Subdistrict, East Kutai District, East Kalimantan Province, Indonesia

\section{Biological conditions of Mesangat Lake}

The vegetation in Mesangat Lake was dominated by water hyacinth (E. crassipes), water spikes (Salvinia molesta) and several types of swamp grass which resulted in the closure of most of the lake's waters. Particular areas were dominated by shame princess plant (Mimosa pigra) while the upstream area in the Kelinjau Ulu River was dominated by water rattan (Calamus sp.), perupuk (Lophopetalum javanicum), rengas (Gluta renghas), Ficus microcarpa and Asplenium nidus.

Sources of food for $C$. siamensis, in general, are fish and snake (Han et al. 2015). There are at least 37 possible species in the Mesangat swamp including 29 fish species that are also found in the Suwi lake (Nugroho et al. 2016). Other natural food sources are based on reference to feed composition which can be an alternative choice that has the potential as food for $C$. siamensis. Based on analysis of food samples from the crocodile's stomach, which averaged $86 \mathrm{~cm}(59-113 \mathrm{~cm})$, the remaining prey components were found, including insects, snails, clams, fish bones, bird feathers, snakeskin scales and hair of small mammals (Behler et al. 2018). Based on the results of this analysis, it appears that the source of feed $C$. siamensis is fish, insects, snails, birds, snakes, small mammals

\section{Habitat preferred by Crocodylus siamensis}

Habitat characteristics favored by $C$. siamensis are presented in Table 3. According to information from several fishermen, $C$. siamensis were often seen resting on floating vegetation, such as Lersiaa hexandra and Eichhornia crassipes, $S$. molesta and grass species such as $H$. malayana. All of these plant species are known as invasive plants and have been invading the Mesangat Lake area.

\section{Nest of Crocodylus siamensis}

The nests of $C$. siamensis were found in Long Balau at coordinates $116^{\circ} 41^{\prime} 48.13^{\prime \prime} \mathrm{E} ; 0^{\circ} 30^{\prime} 55.76^{\prime \prime} \mathrm{N}$ and $116^{\circ} 41^{\prime} 21.05^{\prime \prime}$ $\mathrm{E} ; 0^{\circ} 31^{\prime} 46.76$ "N during floodwaters with water level of \pm 150 $\mathrm{cm}$. Nests were marked with plants on the nest with mounds measuring about $45 \mathrm{~cm}$ high and $75 \mathrm{~cm}$ wide (Figure 4). The nesting habitats are consistent with the species preferred habitats in Mesangat Lake, even though $C$. siamensis in Laos have been reported nesting on land as well as on floating vegetation (Bezuijen et al. 2006, 2012).

According to information from local fishermen that $C$. siamensis nesting season in Mesangat Lake, occurred in March and hatchlings emerged in June 2018. Observation of the nest at the time of the study was experiencing major constraints due to very shallow water conditions in October and November 2018 namely the average depth averaging $40 \mathrm{~cm}$ to $100 \mathrm{~cm}$ and dense aquatic vegetation from the swamp that prevents access to the nest. In December 2018 the presence of the nest was found based on information from fishermen and Ulin Foundation staff. Nest position is far from human activities and rarely passed by fishermen because the area to the location is covered by water plants and swamp grass with an average water level between 60$80 \mathrm{~cm}$.

Based on the Ulin Foundation documentation (2018), the characteristics of active Siamese crocodiles are characterized by mounds made of grass around and the grass has sturdy branches and is not washed away and has a dense density so it is not brittle; around the nest are usually free of grass and sometimes surrounded by floating water plants and there is no sand in the mound because it is always cleaned by the female parent.

Observation results from the nests found, types of plants used as nests by $C$. siamensis are types of Scleria sumatrana grass, Leersia hexandra grass and Cyclosorus interruptus (pakis rawa, swamp fern) (Figure 5). S. sumatrana and L. hexandra grasses have stiff and rough nature so in large amounts of density makes the mound sturdy, strong and not easily washed away. Meanwhile, $C$. interuptus (swamp fern) has brown fiber roots. Nest material is more dominated by twigs, leaves and grass.

\section{Potential threats to Crocodylus siamensis in Mesangat Lake} Invasive plant species

Siltation due to the boom of aquatic invasive plants floating in Mesangat Lake became a threat to $C$. siamensis habitat. At some locations, E. crassipes and S. molesta invaded vast open water areas and blocked the waterways of fishing boats. Besides, this weed after blooming will rotten which causes bad smell. This smell is originated from poisonous hydrogen sulfide compound as a result of anaerobic decomposition of these weeds. 


\section{Habitat fragmentation}

Crocodylus siamensis population occurred in fragmented habitats, sometimes only two or three individuals or even only a group of males without females in one location (Bezuijen et al. 2012). The adults of $C$. siamensis live in a remote place, sometimes in isolated swamp which is not supported by sufficient food. Habitat fragmentation in this area has occurred due to the establishment of oil palm plantations and large forest fires in the 2000s. Fragmentation increases isolation of the remaining population thereby increasing the likelihood of greater extinction.

\section{Overfishing}

Mesangat Lake waters are open access for local fishermen to catch fish, so there is a tendency to compete between fishermen and at the same time with crocodiles. This is supported by the report of Daltry et al. (2003) stated that adult crocodiles have feed preference of particular fishes, although they have a broad diet, including reptiles, birds and even other carcasses.

\section{Discussion}

Wetland areas of Mesangat Lake are not classified as protected or conservation areas. The status of the area is oil palm plantation concession. This situation becomes obstacle for the management of the area, because it must coordinate with the permit holders. Currently, areas of Mesangat Lake have been pressured by human activities namely logging and forest conversion into oil palm plantations, mining and other land uses. Staniewicz et al. (2018) reported that in the region around the lake, there are two threatened crocodile species namely $C$. siamensis and Tomistoma schlegelii.
Table 3. Habitat characteristics favored by Crocodylus siamensis in Mesangat Lake, East Kutai, Indonesia

\begin{tabular}{|c|c|}
\hline Characteristics & Condition \\
\hline Type vegetation & Open water near vegetation \\
\hline $\begin{array}{l}\text { Closure of } \\
\text { vegetation }\end{array}$ & Dense with plants or under the clumps \\
\hline $\begin{array}{l}\text { Availability of } \\
\text { feed sources }\end{array}$ & Abundant fishes or insects \\
\hline $\begin{array}{l}\text { Distance from } \\
\text { settlement }\end{array}$ & Far from human activities \\
\hline Water flow & Stagnant \\
\hline Basking & $\begin{array}{l}\text { On top of floating vegetation or between sub- } \\
\text { merged water vegetation under open conditions }\end{array}$ \\
\hline
\end{tabular}

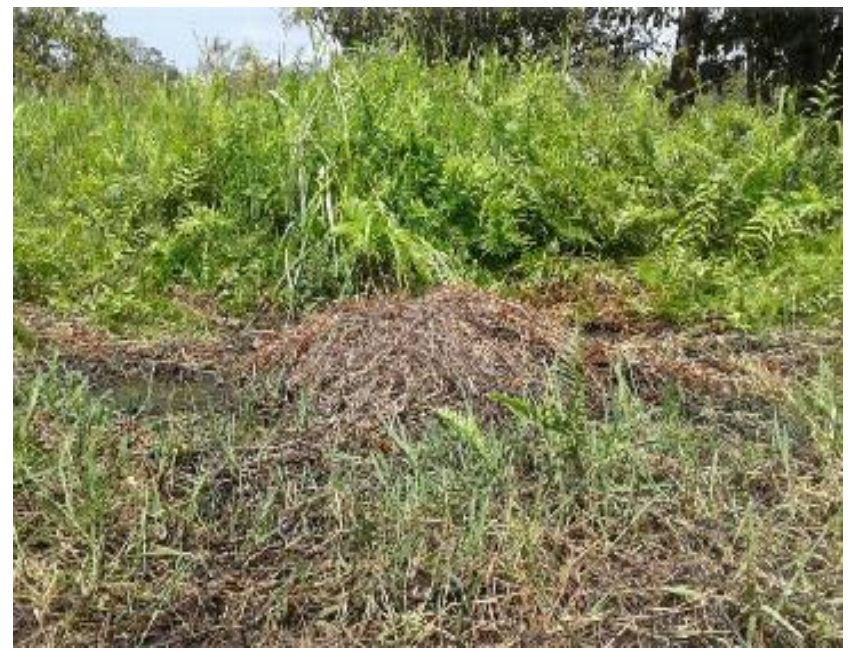

Figure 4. Nests of Crocodylus siamensis

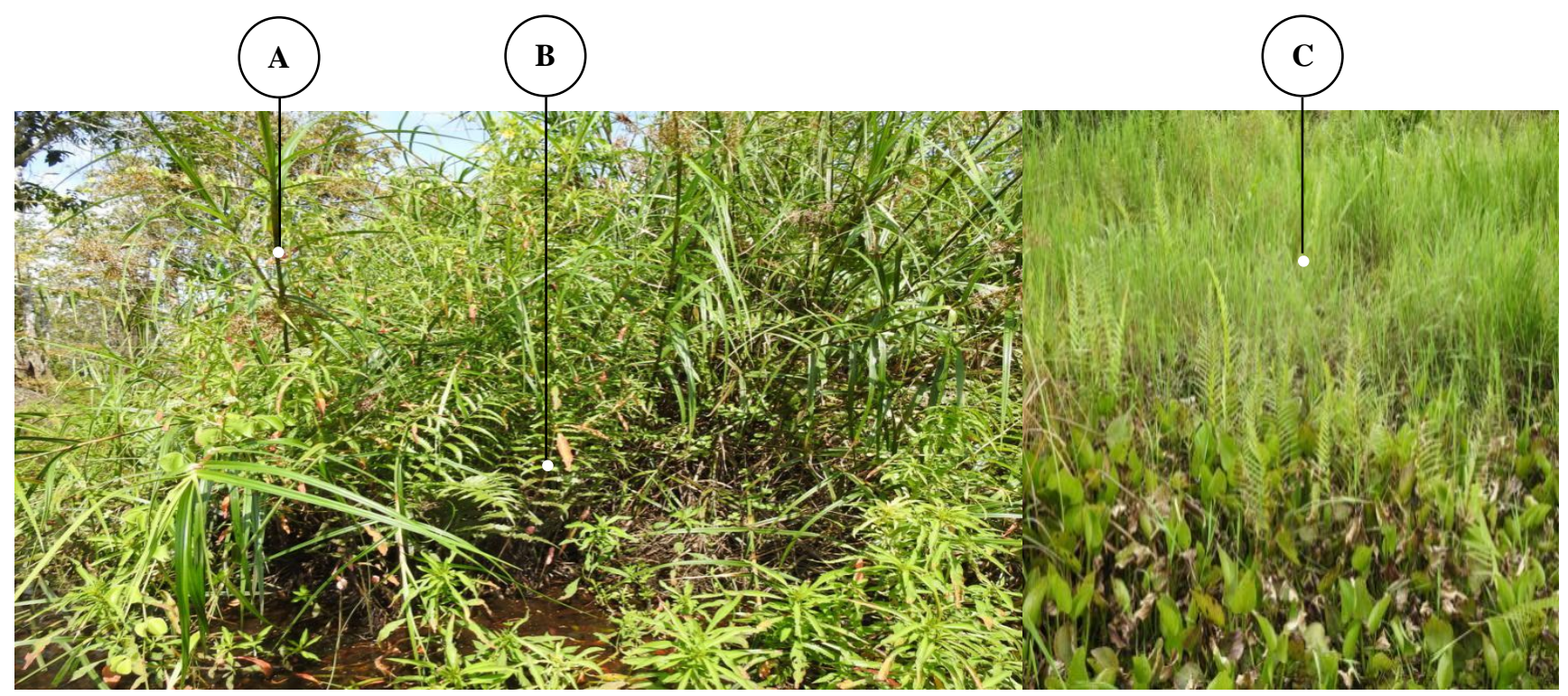

Figure 5. Types of plants making up Siamese crocodile (Crocodylus siamensis) nests in Mesangat Lake, East Kalimantan, Indonesia.A. Scleria sumatrensis (predang), B. Cyclosorus interruptus (swamp fern), C. Leersia hexandra (swamp grass) 
Mesangat Lake, in a natural landscape, forms swamp ecosystem connected to the Suwi Lake wetlands in the south. Both areas have high conservation value and become important habitats for various protected flora and fauna, such as proboscis monkey (Nasalis larvatus), Siamese crocodiles ( $C$. siamensis) as well as various species of water birds, fish, etc. These lakes are integral part of supporting ecological function on the provision of abundant fish resources. However, our study suggested that there is competition between fishermen and C. siamensis in finding fishes. This condition is in line with the results of the study by Han et al. (2015) and Behler et al. (2018) which reported that $C$. siamensis preys include fishes, insects, frogs, snails, birds, snakes, small mammals, and carcasses. Nonkrang (2017) reported in detail about the natural diet of siamensis crocodiles which consists of $52.63 \%$ of fish species, $21.05 \%$ of mammalian species, 5.26 reptile species, and $2.63 \%$ of bird species. Among mammal species, the crocodile diets are mice, crab-eating macaques, and silvery langurs. Based on data from Wahyudi et al. (2017), the research and information from fishermen, there are 63 species of bird, 38 species of fish, 4 species of shrimp, 12 species of mammal and 9 species of reptile in this area. Some fish species with economic value include haruan (Channa striata), toman (Channa micropeltes), biawan (Helostoma temminckii), repang (Cyclocheilichthys enoplos), pepuyu (Anabas testudineus), baung (Mystus micracanthus), sepat (Trichogaster pectoralis), belida (Notopterus sp.), and patin (Pangasius hypophthalmus).

This study indicate that Mesangat Lake has an important role, both from the aspect of biodiversity conservation and economic potential. However, the pressure from overfishing in Mesangat Lake, which is the habitat of $C$. siamensis, is increasing and crocodile adolescents are also caught due to fishing activities. This will threaten the survival of the crocodile. Some fishermen catch $C$. siamensis because there are orders from outside the Mesangat Village.

Various types of swamp plants support C. siamensis. The information of plant occurred in the habitat of $C$. siamensis is important to ensure the protection strategy of C. siamensis by taking into account the potential availability of food sources, nesting, and basking which should be maintained to support the survival of the crocodile in their habitat. However, on the other hand, some invasive aquatic plants pose a threat to $C$. siamensis habitat. The same thing was reported by CAWA (2017), in which two main invasive plant species, namely water hyacinth (E. crassipes) and giant mimosa (M. pigra) have caused a decrease in water quality and siltation of siam crocodile habitat in Laos. Kim et al. (2016) reported that poor environmental conditions have the potential to disrupt the health of siamensis crocodiles by attacking liver and lungs due to necrosis caused by Aspergillus fumigatus.

Various kinds of threat to $C$. siamensis habitat in Mesangat Lake require collaborative conservation efforts to prevent extinction by preserving their habitat. Ecosystem sustainability and $C$. siamensis conservation must involve cooperation with fishing communities. This collaboration is necessary to reduce the impact of dangerous fishing methods as there are many cases of $C$. siamensis trapped by fishing gear or killed by electric shock method used by fishermen. One of the new approaches of conservation outside protected areas is to establish Mesangat Lake wetland as essential ecological areas. Using this approach, an area can be managed for social, economic and cultural uses but still maintain ecological values that play important role in the conservation process. This has been initiated by the Government of Indonesia by closing down several legal logging companies upstream of the Mahakam River to preserve habitat and create partnerships with companies, NGOs, local communities to jointly manage habitats for the survival of $C$. siamensis.

\section{ACKNOWLEDGEMENTS}

The authors would like to thank the Head of Department of Environmental Science, Post Graduate School of Environmental Science, Mulawarman University, Samarinda, Indonesia; The Head of Office of Environmental Service, East Kutai District Government in Sangatta; Suimah from the Indonesian Equatorial Conservation Foundation in Samarinda and fisherman in Mesangat who have supported data this research, as well as the field team for sampling and analysis data. The authors declare that there are no conflicts of interest regarding the publication of this article.

\section{REFERENCES}

Behler N, Kopsieker L, Staniewicz A, Darmansyah S, Stuebing R, Ziegler T. 2018. Population size, demography and diet of the Siamese crocodile, Crocodylus siamensis (Schneider, 1801) in the Mesangat Swamp in Kalimantan, Indonesia. Raffles Bull Zool 66: 506-566.

Bezuijen M, Phothitay C, Hedemark M, Chanrya S. 2006. Preliminary status review of the Siamese crocodile (Crocodylus siamensis Schneider, 1801) (Reptilia: Crocodylia) in the Lao People's Democratic Republic. Mekong Wetlands Biodiversity Conservation and Sustainable Use Programme, Vientiane, Lao PDR

Bezuijen M, Simpson B, Behler N, Daltry J, Tempsiripong Y. 2012. Crocodylus siamensis. The IUCN Red List of Threatened Species 2012: T5671A3048087. DOI: 10.2305/IUCN.UK.2012.RLTS. T5671A3048087.en

CAWA [Climate Adaptation in Wetland Areas of Lao PDR]. 2017. Identification of Spatial Priorities for the Re-opening of Wetlands to Maintain the Water Flow Required for Ecological Functioning, Biological Connectivity and Habitat Maintenance. FAO \& IUCN, Xe Champhone Ramsar Site, Lao.

Cox J, Frazier R, Maturbongs R. 1993. Freshwater crocodiles of Kalimantan (Indonesian Borneo). Copeia 1993: 564-566.

Crocodile Specialist Group. 2013. Siamese Crocodile (Crocodylus siamensis). IUCN Crocodile Specialist Group, Darwin, Australia.

Daltry J, Chheang D, Em P, Poeung M, Sam H, Tan T. 2003. Status of the Siamese Crocodile in the Central Cardamom Mountains, Cambodia. Fauna \& Flora International Cambodia Programme, and Department of Forestry and Wildlife, Phnom Penh.

Han S, Hor L, Nhek R, Sorn P, Heng S, Simpson B, Starr, A, Brooke S, Frecheje JL, Daltry JC. 2015. Status, distribution and ecology of the Siamese crocodile Crocodylus siamensis in Cambodia. Cambodian J Nat Hist 2015: 153-164.

Ihlow F, Bonke R, Hartmann T, Geissler P, Behler N, Rodder. 2014. Habitat suitability, coverage by protected areas and population 
connectivity for the Siamese crocodile Crocodylus siamensis Schneider, 1801. Aquat Conserv Mar Freshw Ecosyst. DOI $0.1002 /$ aqc. 2473.

Kim KT, Lee SH, Kwak D. 2016. Sudden death of a Siamese crocodile (Crocodylus siamensis) due to systemic aspergillosis. J Vet Med Sci 78 (11): 1723-1726.

Nonkrang N. 2017. Prey Species and some behavioral aspect of Siamese crocodile (Crocodylus siamensis (Schneider, 1801) in Khao Yai National Park, Nakhon Ratchasima Province. Wildlife and Range Management, Department of Forest Biology, Faculty of Forestry, Kasetsart University, Bangkok.

Nugroho RA, Santoso YGG, Nur FM, Hariani N, Solikin S. 2016. A preliminary study on the biodiversity of fish in the Suhui River, Muara Ancalong, East Kutai, Indonesia. AACL Bioflux 9 (2): 345351.

Platt S, Sovannara H, Kheng L, Stuart BL, Walston J. 2006. Crocodylus siamensis along the Sre Ambel River, Southern Cambodia: Habitat, nesting and conservation. Herpetol Nat Hist 9 (2): 183-188.
Savini CK, Pliosungnoen M, Pattanavibool A, Thorbjarnarson JB, Limlikhitaksorn C, Platt SG. 2012. A survey to determine the conservation status of Siamese Crocodiles in Kaeng Krachan National Park, Thailand. Herpetol Conserv Biol 7 (2): 157-168.

Simpson BK, Bezuijen MR. 2010. Siamese Crocodile Crocodylus siamensis. In: Manolis SC, Stevenson C (eds.). Crocodiles. Status Survey and Conservation Action Plan. 3rd ed. IUCN Crocodile Specialist Group, Darwin, Australia.

Staniewicz A, Behler N, Dharmasyah S, Jones G. 2018.Niche partitioning between juvenile sympatric crocodilians in Mesangat Lake, East Kalimantan, Indonesia. Raffles Bull Zool 66: 1-10.

Wahyudi D, Kusneti M, Darmansyah S. 2017. Biodiversity inventory and conservation opportunity of Suwi wetlands, Muara Ancalong, East Kalimantan, Indonesia. AIP Conf Proc. DOI: 10.1063/1.4975951. 